\title{
EXEMPTION FROM THE DRAFT: A STUDY IN CIVIL LIBERTIES
}

\section{JULIEN CORNELL†}

A MILITARY draft raises a basic conflict inherent in the democratic process: the right of nonconformist individuals to go their own way against the right of the majority to apply coercion in the name of common necessity. In a society which maintains the principle that civil rights of individuals and minority groups are worthy of special protection even under the pressures of war, the treatment meted out by draft officials and reviewing courts to persons claiming statutory exemption from the draft presents a case study in democratic government which is of far greater importance than the welfare of the individuals involved.

The flood of litigation which has arisen out of the Selective Training and Service Act of $1940^{1}$ has revolved principally around exemptions for three groups: aliens, ministers, and conscientious objectors.

The Act imposes liability for military training and service upon "every male citizen of the United States, and every other male person residing in the United States who is between the ages of eighteen and forty-five . . ." except as otherwise provided. ${ }^{2}$ This clause exempts, by necessary implication, aliens not residing in the United States. In addition, a proviso exempts resident aliens if they are enemies unacceptable to the military forces or neutrals who declare their unwillingness to serve. ${ }^{3}$

Another section " exempts "regular or duly ordained ministers of religion;" "students who are preparing for the ministry in theological or divinity schools," and persons who by reason of "religious training and belief" are "conscientiously opposed to participation in war in any form." While ministers and divinity students are wholly exempt, conscientious objectors are assigned either to non-combatant military service or to "work of national importance under civilian direction."

Under the scheme of the Act, exemption has been accorded only to the groups enumerated above. Persons otherwise liable for service who are not called by reason of physical unfitness, dependency, or occupation are not thereby exempted; their liability for service is merely deferred. Although rulings of draft boards on questions of deferment have sometimes been attacked judicially, the courts have usually refused to review on the ground that responsibility for such decisions rests exclusively with the draft boards. This article is concerned only with cases involving exemption as distinguished from deferment.

† Member N. Y. Bar; author of The Conscientious Objector AND THE LAW (1943).

1. 54 Stat. 885 (1940), as amended, 50 U. S. C., App. $\$ \$ 301-18$ (Supp. 1946) (hereafter cited by section number only).

2. §303(a). See amendment 50 U. S. C. A., App. §303(a) (Supp. 1946).

3. Ibid.

4. $\$ 305$. This section also exempts certain public officials and military officers, classes which can be precisely ascertained and have presented no problem. 


\section{Exemption of Aliens}

Not until World War II did the United States attempt to compel military service of aliens who had not declared their intention to become citizens. In fact, our government until 1940 had always scrupulously insisted upon the exemption of aliens from military service. As early as 1803 , Secretary of State Madison wrote to the French authorities in protest against the drafting of an American citizen residing abroad:

"The most inviolable and most obvious right of an alien resident is that of withdrawing himself from a limited and transitory allegiance having no other foundation than his voluntary residence itself. The infraction of this right is consequently among the greatest of injuries that can be done to individuals, and among the justest of causes for the interposing protection of their government." 5

Both in the Civil War ${ }^{6}$ and World War $I^{7}$ only those aliens who had declared their intention to become citizens were liable for military service; all others, whether resident or not, were exempt.

It is frequently argued that the immunity of aliens from military service is established by international law. The doctrine is that:

"Foreigners cannot be required to perform military service. An exception may be made to this rule where it is necessary to defend a locality against brigands or savages.

"Military service is by its nature a civic and political obligation; it cannot, therefore, be separated from the quality of citizenship. Now since political rights are not ordinarily granted to foreigners, they should not, therefore, be burdened with civic obligations. If they should be compelled to serve under a foreign flag they might find themselves shedding their blood for a cause to which they are indifferent or for interests opposed to those of their native land." 8

Nevertheless, reliance on immunity by international law was unsuccessful in United States 0 . Lamothe ${ }^{9}$ in which a citizen of Haiti, admittedly a resident of the United States, refused to be inducted and challenged Congress' power to compel military service of an alien who had not declared his intention to become a citizen. It was argued that the power to compel military service contained in the Constitution ${ }^{10}$ permitted the raising of armed forces only in accordance with the accepted rules of international law. The court, however, held that the initial Congressional policy of not drafting aliens did not amount to a contemporaneous construction of the Constitution and that no such limitation could be inferred from the language of the Constitution.
5. 4 Moore, A Digest of Internationat LAW (1906) 52.
6. 12 Stat. 731 (1863).
7. 40 Stat. 77 (1917), 50 U. S. C., App. § 202 (1940).
8. Bluntschli, Le Droit International Codifié (1895) §391.
9. 152 F. (2d) 340 (C.C.A. 2d, 1945).
10. U.S. Const. Art. I, \& 8 . 
The present Act subjects to military service only those aliens who reside in the United States. ${ }^{11}$ Since the statute attempts no definition of residence, the Director of Selective Service issued a regulation outlining a general procedure for determining the question. ${ }^{12} \mathrm{By}$ this regulation, aliens who have declared their intention of becoming citizens are deemed to be residents regardless of the length of time they have been in the United States. ${ }^{13}$ Aliens who have not announced such an intention are also considered residents if, within three months of entering the country, they have not applied to a local draft board for a determination of residence and obtained a certificate of non-residence. ${ }^{14}$ In the case of aliens who do so apply, the regulation, like the statute, fixes no standard by which local boards should resolve the question of residence, and in practice most boards have applied the same inflexible three-months test. Thus, in general, any alien remaining in the country for three months has been subjected to the draft.

The categorical application of this rule of thumb, both in the regulation and by the practice of local boards, is plainly not contemplated in the statute, which in no way purports to subject to service aliens who are in fact non-resident. It often happens that business men, students, or tourists visit our shores on temporary missions requiring many months for completion, without any intention of establishing a residence. Whatever evidentiary value mere length of time may have, it can hardly be conclusive of the factual issue. The status of an alien as fixed by the immigration laws, however, affords a yardstick ready-made for these'cases. Aliens entering under the immigration quota are admitted for permanent residence, while those not entering under the quota are usually admitted for a six-months period, which may be extended, and their status is that of non-residents. ${ }^{16}$ In either case an alien's classification by the immigration authorities appears from his visa. The Selective Service officials, however, have consistently ignored this prior determination of status, and many aliens who were clearly non-residents under the immigration laws have nonetheless been drafted. But for unexplained reasons very few such cases have been taken to court. Perhaps it is too much to expect that an alien will have the courage and resources to contest these rulings, especially in wartime.

In Ex parte Ghosh, ${ }^{i 6}$ the only reported case dealing with this discrepancy in policy between the Immigration Department and the Director of Selective Service, the District Court for the Southern District of California said:

11. 54 Stat. 885 (1940), as amended, 50 U. S. C., App. §303(a) (Supp. 1946).

12. Selective Service Regs. $\S 611.13$ (1942). Authority to determine the question of residence was delegated to the Director of Selective Service by the President. ExEc. Order No. 9410, 8 FED. REG. 17319 (1943).

13. Selective Service Regs. § 611.11 (1942).

14. Id. $\S 611.21$.

15. See 43 Stat. 155 (1924), 8 U. S. C. § 204 (1940).

16. 58 F. Supp. 851 (S. D. Cal. 1944). 
"In connection with this matter the determination by the Bureau of Naturalization and Immigration that this man retained his student status and is thus not a resident, must be given weight. He is not, under the Immigration and Naturalization Laws, entitled either to citizenship, or to be a permanent resident of the United States, or a resident at all. . . .

"While it may be argued that such determination is not binding upon the Director of Selective Service nor upon the local board, still the local board did not make any inquiry in that respect, or in that case, when they made their decision on March 10th.

"And after all it is one government, and I do not think it is within the contemplation of our system that a man should be fish before one department and fowl before another. . . ."17

In an unreported case, United States v. Fuhrmann, ${ }^{18}$ the District Court for the Southern District of New York reached a contrary conclusion. A young German who had been studying in the United States was unable because of war conditions to leave the country when his visa expired. Consequently his status under the immigration laws was changed from that of a student admitted for temporary residence to that of an alien subject to deportation for illegally remaining after the date set for his departure, but he never had any intention of remaining permanently in the United States and was still considered a non-resident. Nevertheless, his draft board classified him as subject to military service, and when he refused to be inducted, he was indicted and convicted. In his brief on appeal the accused contended that, being in fact a non-resident alien, he was exempt from military service and could not be compelled to serve. He argued further that failure to file an application for non-resident status with his draft board did not impair his rights since the statutory exemption is absolute and the regulation making exemption conditional is contrary to the statute. Before the case was reached for argument, the United States Attorney consented to dismissal of the indictment. It is not clear whether the United States abandoned the case because its position was untenable or because it did not desire to injure its relations with foreign governments by going on record as compelling military service of their citizens who came to this country as students. In this case the ruling of the draft board was particularly ill-advised because the alien was a German citizen who was being asked to take up arms against his own people and to commit treason against his government. As was stated in Fuhrmann's brief on appeal:

"Surely the thousands of Americans who have studied at Heidelberg and other universities would be appalled to find themselves under any allegiance to Germany, or subject to compulsory service in the German army, merely because of their having sought an education at a German university."

17. Id.at 854 .

18. D. C., S. D. N. Y. File No. C116-289 (Jan. 28, 1944). 
Even though they may have become residents of the United States, citizens of certain countries may claim exemption from military service. Any neutral may be relieved from service upon application, but if he elects to claim this exemption he is specifically debarred from becoming a citizen of the United States. ${ }^{19}$ Moreover, a neutral availing himself of this exemption may incur the additional penalty of rendering himself unable to return to this country if once he leaves it; for the immigration law, with a few minor exceptions, subjects to deportation any one who enters the United States while under a disability which prevents him from becoming a citizen. ${ }^{20}$

Enemy nationals are subject to service only if they are found acceptable to the military authorities. ${ }^{21}$ While such persons have no right to exemption, it has ordinarily been granted when the alien objected to being drafted.

If residing in the United States, citizens of co-belligerent nations are liable for service on the same basis as American citizens. ${ }^{22}$ However, the United States has entered into a series of treaties with co-belligerent nations providing that before either party compels military service of citizens of the other who reside within its territory, it will give such persons an opportunity to enlist in the armed forces of their native country. Such treaties have been negotiated with eighteen countries: Australia, Belgium, Brazil, Canada, Colombia, Cuba, Czechoslovakia, El Salvador, Greece, India, Mexico, New Zealand, Netherlands, Norway, Poland, Union of South Africa, United Kingdom and Yugoslavia. Citizens of co-belligerent nations with which no such treaties have been concluded may not claim, as of right, the privilege of enlisting in their own forces. Governments of co-belligerent nations not party to such treaties have on occasion unsuccessfully objected to this feature of our draft law.

In some cases the statute compels military service of aliens in violation of pre-existing treaties. While there is nothing to prevent the United States, by legislative enactment, from refusing to honor its international obligations, the wisdom of such action by a nation which consistently proclaims the sanctity of treaties seems doubtful. This situation was discussed in a letter from the Secretary of State to the Speaker of the House of Representatives, dated April 15, 1941, in which he wrote:

"The Selective Training and Service Act of 1940 provides for the registration of all male aliens within specified ages residing in the United States and makes such aliens who have not declared their intention to become citizens of the United States liable for training and service.

"The Department has received communications from a number of foreign diplomatic missions complaining that nationals of their

19. 55 Stat. 845 (1941), 50 U. S. C., App. \& 303(a) (Supp. 1941).

20. 43 STAт. 162 (1924), 8 U. S. C. $\$ 213$ (c) (1940).

21. 54 Stat. 885 (1940), as amended, 55 Stat. 845 (1941), 50 U. S. C., App. $\$ 303$ (a) (Supp. 1946).

22. Ibid. 
countries are being drafted for training and service. Some of these complaints are based on treaty provisions and the Mexican Embassy has taken the position that the drafting of its nationals for military service is contrary to the principles of international law."

\section{Ministers of ReLigIoN}

The statutory provision extending absolute exemption to ministers and students preparing for the ministry ${ }^{23}$ was copied almost verbatim from the Act of $1917 .{ }^{24}$ Both statutes require, as prerequisites to exemption, that ministers be duly ordained and students be enrolled in recognized divinity or theological schools.

The reason for exempting ministers and students preparing for the ministry is not readily apparent. It may be that Congress felt that the spiritual guidance of ministers in wartime was essential to the national well-being. Or it may be that Congress was influenced by the basic pacifist character of the Christian religion and did not wish to place those who had dedicated themselves to following the teachings of Christ in a position where they would have to abandon their principles by engaging in warfare. Still another explanation has been offered. Many prominent ministers are avowed pacifists and would refuse to be drafted. The imprisonment of such leaders might encourage pacifism, a result to be avoided in wartime. Whatever the explanation may be, in most cases ministers have gladly accepted the exempt status which the law gives them, although some have complained that the clergy should not be so privileged and have refused to claim exemption.

Most of the litigation about the exemption for ministers has concerned the Jehovah's Witnesses. This is a militant evangelistic group operating chiefly through a corporation known as The Watch Tower Bible and Tract Society which was chartered in New York in 1909, maintains headquarters in New York City, and operates its own printing and publishing house and broadcasting station. The corporation prints and distributes bibles, books, magazines, pamphlets and other tracts which are used and sold by its members in spreading their views. The Jehovah's Witnesses rely almost entirely upon the Bible as a direct revelation of the word of God and condemn all established churches as deviating from the truth. The sect maintains no churches but acts through direct canvassing by its members, all of whom regard themselves as ministers.

The Jehovah's Witnesses have been persecuted even more than most unpopular minorities. Frequently their methods of house-to-house appeal and their condemnation of other religious organizations have led the police to restrict their activities. Likewise local authorities have tried to expel their children from public schools for refusing to salute the flag in the belief that to do so would violate the biblical injunction against graven images. ${ }^{25}$ When-

23. 54 Stat. 888 (1940), 50 U. S. C., App. § 305(d) (1940).

24. 40 Stat. 78 (1917), 50 U. S. C., App. § 204 (1940).

25. Such expulsion was finally held to be a violation of the Fourteenth Amendment 
ever discriminated against, however, they have diligently and ably defended their rights in the courts, and the result has been a long series of far-reaching decisions on civil liberties. With no less zeal they have pressed their claims to exemption under the Selective Service and Training Act, and the sect has been responsible for more than half the cases appealed to higher courts.

The Jehovah's Witnesses have uniformly maintained in the courts that they are all ministers. It is their belief that:

"Any individual of sound mind and mature in years, who has a knowledge of God's Word and appreciates His commands, and who then makes a full consecration unto God to do His will, is ordained of God to be His servant, for ever, if he maintains his covenant. . . . One who has consecrated his life to the service of the Most High will preach the gospel of the Kingdom as he has opportunity, and really puts forth every effort to do that. One docs not go to a theological seminary or school to be an ordained minister of the gospel. To go there would mean that he was ordained of men to preach God's Word; whereas the only One who can give the real authority to preach the Word of God is Jehovah himself, even as he gave it unto His Son. (Isa. 61: 1, 2)." 26

As a result, every Jehovah's Witness has claimed exemption as an ordained minister. The Director of Selective Service found it necessary to lay down some test by which these claims could be judged. The theory that ordination comes directly from God makes it impossible to apply ordination as a test since all Jehovah's Witnesses regard themselves as ordained. Many of them, however, hold secular jobs and confine their ministry to spare time. In such cases the Director of Selective Service has ruled that they do not merit exemption as ministers. In order to determine which of those who claim to be full time ministers are actually so engaged, the Director of Selective Service in 1943 compiled a list of the 6278 Witnesses who were classified by the Society as "Pioneer Publishers." These "Pioneers" are required to put in 150 hours a month, or an average of 5 hours a day, in service of their Society. ${ }^{27}$ Information from the master list was given to local draft boards, which were instructed to grant or deny exemption according to whether or not the name of a claimant appeared on the list. Apparently the theory was that those Witnesses who were recognized by the sect as devoting 150 hours a month to the ministry were full time ministers and should be exempt, whereas those not so recognized should not be exempted.

In many cases, however, a Jehovah's Witness might be spending full time in the ministry and yet not be listed as a "Pioneer Publisher." In such case he was automatically denied exemption under the method of classification

in Barnette v. West Virginia State Board of Education, 319 U. S. 624 (1943), overruling Minersville School Dist. v. Gobitis, 310 U. S. 586 (1940).

26. 1944 Yearbook of Jemovar's Witnesses (1943) 32-3.

27. Id. at 61 . 
set up by the Director of Selective Service. Here the courts have rightly held that it was error for a draft board not to make an independent inquiry into the facts. ${ }^{28}$

A further question raised by the exemption of ministers and divinity students relates to the recognition of rabbis and rabbinical students of unorthodox faith. Selective Service officials in New York City experienced difficulty in dealing with claims for exemption presented by unorthodox rabbis and rabbinical students in small seminaries which were unrecognized by orthodox Judaism. Whether or not such rabbis and rabbinical schools should be recognized under the Act involved conflicts in Hebraic faith and practice which were quite beyond the ability of draft boards to understand. Accordingly, the Selective Service officials in New York City referred such questions to a special advisory panel of five eminent rabbis and laymen: Rabbi Herbert Goldstein, Judge Jonah J. Goldstein, Rabbi Elias Solomon, Dr. Samuel Nirenstein and Mr. Bernard Sewel. The panel held hearings, kept minutes of its proceedings, and made recommendations to Selective Service headquarters. Members of the panel, although men of high standing and integrity, were of orthodox belief and could not help but express in their findings some of the sharp cleavage and bitterness which exists between orthodox rabbinical circles and some of the modern offshoots of Judaism.

A case which reflects this situation is United Slates ex rel. Traininz. Cain $=$ which arose upon a writ of habeas corpus to determine whether a draft board had erred in denying exemption to a young rabbi upon the recommendation of the special advisory panel. The relator had never attended a rabbinical seminary but had studied under his father. He claimed he had been ordained by his father and two other rabbis, and his local draft board received communications from two rabbinical societies certifying that he was a member and a rabbi. He claimed also to have a congregation which had been founded by his father, who had recently retired; that he was principal of a Hebrew school for children of the congregation; and that he performed marriages and funerals. The congregation, however, numbered only twenty to thirty, and the school had but ten pupils. Furthermore, there was evidence that the father was considered the true rabbi of the congregation. The advisory panel found him to be lacking in rabbinical lore and in knowledge of Hebraic testaments. It was the relator's contention, however, that the advisory panel questioned him about orthodox rabbinical beliefs with which he was unfamiliar, and that the panel was not qualified to investigate his rabbinical qualifications because of the unorthodoxy of his beliefs. He pointed out that his rabbinical status was attested to by five rabbis of his own faith and maintained that this was conclusive. The only unfavorable evidence, he contended, was submitted by members of rival branches of his faith who, in effect, asserted only that his qualifications and ordination were

28. See United States v. Balogh, C.C.A. 2d, Oct. 31, 1946.

29. 144 F. (2d) 944 (C.C.A. 2d, 1944). 
not in accordance with their own requirements. The court held that judicial review of draft board classifications extended only to determination of whether a board had any evidence to sustain its ruling, and in this case it was held that such evidence could be found and that the ruling would therefore not be disturbed. A reading of the opinion, however, leaves one in doubt as to whether the relator may not have been the victim of sectarian jealousies. ${ }^{30}$

The same court, in United States ex rel. Levy v. Cain, ${ }^{31}$ later circumscribed the use which could be made of the advisory panel. A local board had denied the relator exemption as a rabbinical student upon a panel recommendation which stated merely that his status did not warrant such a classification. The court held that in following this "general verdict" the board had abdicated its statutory duty by relying on the panel, not only for expert opinion on incidental ecclesiastical questions, but for a determination of the entire issue in the case. Accordingly, the relator was ordered released from custody of the army without prejudice to further proceedings before the draft board. ${ }^{32}$ In discussing the type of issue which might properly be referred to the panel, the court stated that the local board could seek advice on such questions as the standing and character of a seminary, whether that standing was being impaired by allowing the seminary to be used for draft evasion, and whether the relator was honestly pursuing a course of rabbinical studies with intention of becoming a rabbi; but could not submit to the panel such questions as whether the registrant was trustworthy or whether the seminary was abetting an attempt to evade the draft.

\section{CONSCIENTIOUS OBJECTORS}

Exemption from combatant training and service is granted under the Act to "any person . . . who, by reason of religious training and belief, is conscientiously opposed to participation in war in any form." ${ }^{33}$ Such persons are to be inducted and assigned to non-combatant service as defined by the President. In practice, they are put in medical units of the army and navy. The Act also provides that persons who have conscientious objections even to such non-combatant service shall, "in lieu of such induction, be assigned to work of national importance under civilian direction." 34 Such persons have been placed in work camps and in some cases permitted to volunteer as guinea pigs in medical experiments, as parachute fire fighters, and for other welfare projects.

30. The case went so far as to involve such sectarian niceties as whether the certificate of ordination was valid if it did not contain the Hebraic words "Yoreh Yorch" or "Yodin Yodin" which certain rabbis termed essential to a valid ordination.

31. 149 F. (2d) 338 (C.C.A. 2d, 1945).

32. It was also held that the procedure followed by the panel was improper in that the names of the panel were not disclosed to the registrant so that he could effectively challenge the members for bias or predilection.

33. 54 Stat. 889 (1940), 50 U. S. C. App. $\& 305$ (g) (1940).

34. Ibid. 
The foregoing exemption is much broader than the World War I exemption, which extended only to members of "any well-recognized religious sect or organization at present organized and existing and whose existing creed or principles forbid its members to participate in war in any form and whose religious convictions are against war or participation therein in accordance with the creed or principles of said religious organizations. . . " ${ }^{35}$ Besides being thus restricted to members of certain religious sects, the 1917 exemption contained another limitation not included in the present statute. The exemption extended only to combatant service, and no provision was made for men who objected also to service in non-combatant military capacities.

While more liberal than its World War I counterpart, the present Act still fails to recognize the conscientious scruples of a substantial number of persons: those unwilling even to register for conscription or unwilling to perform any service whatever under a conscription statute; those whose objections have a political, humanitarian and philosophical, rather than a "religious," basis; and those willing to fight in some circumstances and thus not opposed to "participation in war in any form" but unwilling to engage in the type of struggle for which the draft was invoked.

The English law, ${ }^{36}$ in contrast, makes special provisions for these groups. A separate register is maintained for conscientious objectors. Persons unwilling to serve in any capacity, civilian or military, under a conscription statute may claim total exemption, which has been granted to about six per cent of English conscientious objectors. There is no religious test of objection, and the question is merely whether the objections are conscientiously held. Nor need an Englishman object to "war in any form." Exemption was even granted to an Indian nationalist who had no objection to war as such, but was unwilling to fight for the British Empire so long as India was held in subjection. ${ }^{37}$ The British authorities apparently reasoned that a political objection should be regarded as within the statute when so deeply held that it became a matter of inner conviction as to right or wrong and not merely a matter of opinion or personal expediency.

Another important difference between the British and American statutes is that the British law provides for the assignment of conscientious objectors to ordinary jobs at current wages, or to fire fighting or other public service. In practice they have been assigned to work in their own communities in employment for which they are particularly qualified and have been able to live with and support their families. Under the American system conscientious objectors unwilling to perform non-combatant military service have been herded into concentration camps where they have worked without pay, usually in menial jobs of little public significance. After the system had been in operation for some time, some objectors were released from the

35. 40 Stat. 78 (1917), 50 U. S. C., App. § 204 (1940).

36. National Service (Armed Forces) Act, 1939, 2-3 Geo. VI, c. 81, § 5, as amended.

37. Bulletin, Central Board for Conscientious Objectors (London, May, 1944 ) 8. 
camps to undertake work in mental hospitals, on farms, in medical experiments, and in parachute fire fighting. However, they still received no pay and were invariably sent to communities far distant from their homes.

For refusal to go to work camps, failure to register, or unwillingness to be inducted after being denied exemption, several thousand conscientious objectors have been imprisoned under sentences ranging up to five years. Among this number have been many Jehovah's Witnesses who, after unsuccessfully claiming to be ministers, were classified as conscientious objectors but refused to report to work camps on the ground that they would thereby be prevented from exercising their calling as ministers. As of June 30,1944 , a total of 4,363 conscientious objectors had been convicted. Of this number 3,224-including over twenty-five hundred Jehovah's Witnesses-then remained in prison. ${ }^{38}$ Conscientious objectors at that time comprised about one-sixth of the entire Federal prison population ${ }^{39}$ and accounted for about two-thirds of the men imprisoned for draft violations. These figures are in startling contrast to like statistics in Great Britain where in August, 1944 only about two hundred conscientious objectors, including Jehovah's Witnesses, were in prison ${ }^{40}$ although the entire number of conscientious objectors was far greater than in this country. About fifteen hundred conscientious objectors remain in American prisons ${ }^{41}$ as compared with thirteen still in British prisons. ${ }^{42}$

It is apparent from the large number of Jehovah's Witnesses and conscientious objectors found in prisons that this problem has been one of very real importance to the government. The maintenance of these men at the peak cost over two million dollars per year, and the aggregate cost of kceping them in prison will probably amount to ten million dollars. Not only has this expense been imposed upon the taxpayers, but the labor of several thousand able bodied men has been lost to the nation. It was this situation which led a Canadian official to state that Canada with its labor shortage during the war could not afford the "emotional luxury" of keeping such men in concentration camps. ${ }^{43}$

The most important question involving conscientious objectors which has arisen in the courts concerns the construction of the phrase "religious training and belief." Many conscientious objectors who did not happen to

38. Annual Report of Director Bureau of Prisons (1944) 45, n. d.

39. Out of a total of 18,392 prisoners on June $30,1944,3,224$ were conscientious objectors. Op. cit. supra note 38 at 44. 29.

40. Bulletin, Central Board for Conscientious Onjectors (London, Aug., 1944)

41. Attorney General Clark, in a letter of Aug. 8, 1946, to the Committce for Amnesty, stated that there were then about 1250 Jehovah's Witnesses and 175 other conscientious objectors in federal prisons.

42. Letter from Central Board for Conscientious Objectors, London, to Committeo for Amnesty July 31, 1946.

43. The Reporter, National Service Board for Religious Objectors (Aug. 15, 1944) 7 . 
belong to a church, or whose views ran along unorthodox lines, have been denied exemption and have attempted to obtain from the courts a construction of the statute broader than that followed by their draft boards.

The necessity for a construction of this phrase was recognized early when one of the several hearing officers appointed by the President to investigate and report on claims of conscientious objectors wrote to the Attorney General for advice on the meaning of "religious training and belief." The Attorney General referred the matter to the Director of Selective Service, General Hershey, who issued an opinion that no one could be recognized as a conscientious objector under the statute unless he believed in "some source of all existence which is divine because it is the source of all things." 44 In other words, General Hershey construed "religious training and belief" as requiring belief in a deity which is the creator of the universe. Under this definition exemption has been denied to objectors whose views were based upon political, humanitarian and philosophical grounds but who did not profess belief in a deity. Exemption has also been denied to persons who would ordinarily be regarded as religious, such as humanists and members of the Ethical Culture Society, because their worship centers around mankind and because they do not use the word "God" and do not accept the orthodox conception of deity even though they do believe in spiritual force. In practice, draft boards have also tended to identify religion with church affiliation. For example, persons unable to demonstrate church membership as well as orthodox theological views, have found difficulty in obtaining exemption, although the statute clearly covers them.

The question of the meaning of "religious training and belief" first reached the courts in the case of Mathias Kauten, who was found by Honorable Lamar Hardy, hearing officer, to be a sincere conscientious objector, but to lack religious beliefs because he professed to be an atheist. He was a man of unusual character and integrity, an artist whose objection to war arose out of his views of the brotherhood of man. Having refused to appear for induction, he was indicted and tried in the District Court for the Southern District of New York, where he offered the defense that the induction order was invalid because based upon an erroneous classification. His conviction was sustained by the Second Circuit, which held that error of classification could not be raised by one who had refused to be inducted. Such a question could be raised, the court said, only by way of a writ of habeas corpus after induction into the armed forces. ${ }^{45}$ In a subsequent case the Supreme Court held this ruling erroneous. ${ }^{46}$ In passing, however, the Circuit Court discussed the meaning of the disputed phrase "religious training and belief," and its dictum has been followed and applied generally by courts and by

44. Letter to Dep't of Justice, Mar. 5, 1942.

45. United States v. Kauten, 133 F. (2d) 703 (C.C.A. 2d, 1943).

46. Estep v. United States, 327 U. S. 114 (1946), discussed infra p. 275. 
many draft officials. Speaking through Judge Augustus N. Hand, the court said:

". . the provisions of the present statute ... take into account the characteristics of a skeptical generation and make the existence of a conscientious scruple against war in any form, rather than allegiance to a definite religious group or creed, the basis of exemption. . . . A compelling voice of conscience ... we should regard as a religious impulse. . . .

"It is unnecessary to attempt a definition of religion; the content of the term is found in the history of the human race and is incapable of compression into a few words. Religious belief arises from a sense of the inadequacy of reason as a means of relating the individual to his fellow-men and to his universe-a sense common to men in the most primitive and in the most highly civilized societies. It accepts the aid of logic but refuses to be limited by it. It is a belief finding expression in a conscience which categorically requires the believer to disregard elementary self-interest and to accept martyrdom in preference to transgressing its tenets. . . .

"There is a distinction between a course of reasoning resulting in a conviction that a particular war is inexpedient or disastrous and a conscientious objection to participation in any war under any circumstances. The latter, and not the former, may be the basis of exemption under the Act. The former is usually a political objection, while the latter, we think, may justly be regarded as a response of the individual to an inward mentor, call it conscience or God, that is for many persons at the present time the equivalent of what has always been thought a religious impulse." 47

It will be noticed that Judge Hand rejected entirely the argument of Selective Service officials that the word "religious" in the statute requires that conscientious objection to war must be based on orthodox theological beliefs. In the court's view, the promptings of conscience are essentially religious in character, even though church, creed, and God are all denied. Regarded in this light, the word "religious" as used in the law merely emphasizes the term "conscience" as meaning the compelling voice of some inward spiritual guide rather than a mere conviction based on intellectual judgment or expediency.

This interpretation avoids the pitfall into which draft officials have often fallen. They have felt obliged to insist that mere conscience alone is not enough for exemption; in addition there must be some religious element added to conscience, because the law contains the word "religious" as well as the word "conscientious." The court resolved this verbal difficulty by pointing out that true conscience is religious in nature.

Not long afterwards the dictum of the Kauten case was solidified into a holding by the same court in United States ex rel. Phillips v. Downer ${ }^{48}$ when

47. United States v. Kauten, 133 F. (2d) 703, 708 (C.C.A. 2d, 1943).

48. 135 F. (2d) 521 (C.C.A. 2d, 1943). 
the question was presented, as the court indicated in the Kaulen case that it should be, by a writ of habeas corpus after induction. Phillips had been denied exemption partly on the ground that his objection was not religious within the meaning of the statute because his views were based upon philosophical and humanitarian concepts, rather than orthodox theology. The court held the denial erroneous because based upon a different conception of the religious test from that stated in the Kauten opinion.

The Phillips case was followed in United States ex rel. Reel v. Badt, ${ }^{43}$ also decided by the Second Circuit. The court reiterated the views expressed in the Kauten case that so long as an objector's conscientious scruples are based on his response to an inward mentor, whether it be called conscience or God, belief in a deity is not required. ${ }^{50}$

The Department of Justice did not petition for certiorari in the above cases and presumably was content with the rule enunciated in the Second Circuit. The Director of Selective Service, General Hershey, however, persisted in his former view, and many draft boards have followed his lead. In his report covering the year following Pearl Harbor, General Hershey repeated his construction of the law as requiring belief in "a Deity or a power above and beyond the human." 51

The attitude of the Director of Selective Service on this question has been of utmost importance because he stands at the top of the quasi judicial bodies which pass upon exemptions for conscientious objectors. Decisions by the draft boards may be appealed to the President when the appeal board is not unanimous, and in all cases where necessary to prevent injustice or to correct an error of law the Director of Selective Service, either upon his own motion or upon request of a draftee, may order that an appeal to the President be taken..$^{52}$ The responsibility of deciding appeals to the President has been delegated by him to the Director of Selective Service. ${ }^{53}$ General Hershey, therefore, has been the last administrative resort, and his construction of the law necessarily has great weight with draft boards-perhaps greater weight than the views of the Federal courts since in most cases conscientious objectors have been unable to persuade the courts to take jurisdiction.

Despite the intransigence of General Hershey on this subject, other officials have approved the law laid down in the Second Circuit. The Department of Justice, for example, instructed draft boards in federal prisons to follow the Kauten and Phillips decisions in reclassifying conscientious objectors. ${ }^{54}$

The construction placed upon the statute by the Second Circuit has been

49. 141 F. (2d) 845 (C.C.A. 2d, 1944).

50. Id. at 847 .

51. Selective Service in War Tume (Selective Service System, 1943) 258.

52. Selective Service Regs. $\$ \S 628.1,628.2$ (1942) as amended.

53. EXEc. Order No. S619, 5 FEd. REg. 5256 (1940).

54. Memorandum dated April 15, 1944. 
sharply criticized by one writer ${ }^{55}$ as amounting to judicial legislation, and the contrary view has been recently adopted by the Ninth Circuit in Berman v. United States, ${ }^{56}$ with one judge dissenting. Petition for certiorari in the latter case was denied ${ }^{57}$ apparently on the ground, as urged by the government, that the case was properly decided on the facts and that the disputed construction of the statute was not necessary to the decision.

\section{Judicial REview*}

A technical question of much interest which arose out of draft exemption is the matter of judicial review of Selective Service rulings. Although the body of administrative law has been greatly expanded in recent years, the circumstances under which courts will review rulings and the extent of such review have not been finally settled. The unsettled state of the law is reflected in the cases relating to judicial review of draft classifications.

The Selective Training and Service Act provides, ${ }^{58}$ like the $1917 \mathrm{draft}$ law, ${ }^{59}$ that the decisions of draft boards shall be final. However, it is wellsettled that in spite of this provision the courts will review draft board decisions when (1) a full and fair hearing has been denied; (2) the decision is arbitrary, capricious and unreasonable on an issue of fact; or (3) the decision is contrary to law. ${ }^{60}$ When one of these conditions occurs, the courts will not consider the case de novo, but will merely review the record of proceedings before the draft boards.

As to the scope of such review there is a divergence of opinion in the courts. Some courts have applied the usual rule of administrative law that review of the facts is limited to ascertaining whether there is substantial evidence to support the findings. ${ }^{61}$ Others have held that judicial inquiry extends only to a determination of whether there is any evidence whatever to support the findings, ${ }^{62}$ and still other courts have restricted their review to the question of whether a board has considered all the evidence presented

55. Waite, Section 5(g) of the Selective Service Act as Amended by the Cottrt (1944), 29 Minn. L. Rev. 22.

56. 156 F. (2d) 377 (C.C.A. 9th, 1946).

57. December 23, 1946, 15 U. S. L. WeEK 3240.

* Compare the author's point of view on judicial review of Selective Service rulings with that expressed in NoTE (1946) 56 YALE L. J. 403 infra.-Ed.

58. 54 Stat. 893 (1940), 50 U. S. C., App. $\$ 310$ (a)(2) (1940).

59. 40 Stat. 78 (1917), 50 U. S. C., App. $\$ 204$ (1940).

60. See United States ex rel. Pascher v. Kinkead, 248 Fed. 141 (D. N. J. 1918), aff'd 250 Fed. 692 (C. C. A. 3d, 1918); Angelus v. Sullivan, 246 Fed. 54 (C.C.A. 2d, 1917).

61. Benesch v. Underwood, 132 F. (2d) 430 (C.C.A. 6th, 1942); Rase v. United States, 129 F. (2d) 204 (C.C.A. 6th, 1942); United States v. Messersmith, 138 F. (2d) 599 (C.C.A. 7th, 1943); Graf v. Mallon, 138 F. (2d) 230 (C.C.A. 8th, 1943); Seele v. United States, 133 F. (2d) 1015 (C.C.A. 8th, 1943); Arbitman v. Woodside, 258 Fed. 441 (C.C.A. 4th, 1919).

62. United States ex rel. Trainin v. Cain, 144 F. (2d) 944 (C.C.A. 2nd, 1944); Checinsk v. United States, 129 F. (2d) 461 (C.C.A. 6th, 1942). See United States v. Buttecali, 46 F. Supp. 39 (S. D. Tex. 1942), aff'd 130 F. (2d) 172 (C.C.A. 5th, 1942). 
to it-in other words, whether the board accorded the registrant procedural due process of law. ${ }^{63}$

Even more important than the scope of judicial reviev has been the tendency of most courts automatically to apply to draft decisions the general rule of administrative law that the order of an administrative agency may not be challenged by one who has disobeyed it. Early in the administration of the statute this rule was applied in the Third Circuit ${ }^{\text {os }}$ in a case involving a Jehovah's Witness who had been denied exemption as a minister. When ordered to report for induction, the registrant refused and pleaded that the board's action was arbitrary, capricious and unreasonable, and its order therefore invalid. The court declined to entertain this defense and refused to review the draft classification on the ground that the registrant, having disobeyed the order, could not attack it collaterally in a criminal proceeding based upon such disobedience, but must first submit to induction as ordered and then raise the issue by seeking a writ of habeas corpus. Throughout most of the war, this view was followed in all circuits except the Fourth. ${ }^{55}$

The Supreme Court first passed on this question in Falbov. Unitad Slates, ${ }^{\text {cs }}$ in which it upheld the interpretation previously evolved in the circuits. A Jehovah's Witness, Nick Falbo, had been convicted for refusing to report to a camp for conscientious objectors after being denied exemption as a minister. The Supreme Court held that he had not completed the Selective Service process, which comes to an end only when one reports for induction or assignment to a conscientious objectors' camp, and consequently could not question the validity of his classification. Justice Murphy filed a dissenting opinion criticizing the artificiality of the court's reasoning.

The practical result of the approach taken by the Circuit Courts of Appeal and approved in the Falbo case usually. was to deny any review whatever. Few Jehovah's Witnesses or conscientious objectors have been villing to submit to induction, since a subsequent denial of habeas corpus would leave them subject to military jurisdiction. Their choice would then be between sacrificing their principles by participating in military activities or laying themselves open to imprisonment or even death as a court martial might

63. Ex parte Stanziale, 138 F. (2d) 312 (C.C.A. 3d, 1943); Crutchfield v. United States, 142 F. (2d) 170 (C.C.A. 9th, 1943). See also (1942) 10 Geo. WAsE. L. Rev. 827, 837-S.

64. United States v. Grieme, 128 F. (2d) 811 (C.C.A. 3d, 1942).

65. Sirski v. United States, 145 F. (2d) 749 (C.C.A. 1st, 1944); United States v. Flalsowicz, 146 F. (2d) 874 (C.C.A. 2d, 1945); United States v. Estep, 150 F. (2d) 768 (C.C.A. 3d, 1945), res'd, 327 U. S. 114 (1946); Fletcher v. United States, 129 F. (2d) 262 (C.C.A. 5th, 1942); United States v. Rinko, 147 F. (2d) 1 (C.C.A. 7th, 1945); Gibson v. United Stztes, 149 F. (2d) 751 (C.C.A. 8th, 1945). But see Goff v. United States, 135 F. (2d) 610 (C.C.A. 4th, 1943); Baxley v. United States, 134 F. (2d) 998 (C.C.A. 4th, 1943).

Compare British decisions allowing full judicial review under the World War I draft: Hawkes v. Moxey, 86 L.J. K. B. (N.s.) 1530 (1917); Offord v. Hiscocl, 86 L.J. K. B. (N.S.) 941 (1917).

66. 320 U. S. 549 (1914). The question had first been presented to the Supreme Court in 1943, but the case went off on another issue, Bovles v. United States, 319 U. S. 33 (1913). 
direct. ${ }^{67}$ Moreover, some of the few hardy souls who have submitted to induction have undergone severe treatment at the hands of military authorities. ${ }^{68}$ It is thus a severe burden which the courts have imposed upon such persons by holding that induction is a prerequisite to judicial review.

The reason for the general rule which prohibits attack on administrative orders by those who have disobeyed them is the promotion of convenience and orderly procedure. However, it is difficult to see how administrative convenience is promoted by requiring a man to submit to induction before he can question the acts of his draft board. The order of induction is the last step in the administrative process. The draft board has then closed its files and completed the case. The induction ceremony is conducted by the military forces. The refusal to be inducted occurs at a point where the entire administrative procedure is over and the drafted man has been delivered to the military authorities. It can hardly be said that judicial review at this point would interfere with the draft process, since that has already been completed.

Only a few months after the Falbo case was decided, the Court narrowed its import. In Billings v. Truesdell ${ }^{69}$ it was held that one who had reported for induction but refused to take the oath of induction, could not forcibly be inducted and could by writ of habeas corpus secure release from the military authorities. The rationale was that military jurisdiction does not apply until a person has been actually inducted and that induction can be accomplished only by administering a voluntary oath. The somewhat strained distinction between reporting for induction and taking the oath was apparently concocted to soften the harsh effect of the Falbo ruling, for at the end of its opinion the court went beyond the issues immediately confronting it to state:

"Moreover, it should be remembered that he who reports at the induction station is following the procedure outlined in the Falbo case for the exhaustion of his administrative remedies. Unless he follows that procedure he may not challenge the legality, of his classification in the courts. But we can hardly say that he must report to the military in order to exhaust his administrative remedies and then say that if he does so report he may be forcibly inducted against his will. That would indeed make a trap of the Falbo case by subjecting those who reported for completion of the Selective Service process to more severe penalties than those who stayed away in defiance of the board's order to report." 70

The plain implication of this passage was that the requirements for judicial review of draft board classifications would be met by reporting at an induc-

67. Articles of WAR, ART. 64, 41 Stat. 801 (1920), 10 U. S. C. $\$ 1536$ (1940).

68. See Cornell, The Conscientious Objector and the Law (1943) 52-6.

69. 321 U. S. 542 (1944).

70. Id. at 558-9. 
tion center, although thereafter the oath of induction was refused. By following this procedure, a registrant would remain under civil jurisdiction and, if prosecuted for refusing actually to be inducted, could defend on the ground that the classification was unreasonable.

Lower courts, however, seemed unable to accept the obvious fact that the Supreme Court had in the space of three months reversed itself by this backhanded method, and they continued to deny judicial reviev to those who, following the procedure suggested in the Billings case, reported for induction but refused to take the oath. ${ }^{71}$ The matter was finally put to rest, but not until February, 1946, when the Supreme Court squarely held in Estep v. United States ${ }^{72}$ that a registrant who completed the Selective Service process by reporting for induction but refused to take the oath of induction and was indicted for such refusal could directly challenge the validity of his classification and need not first submit to military jurisdiction and then raise the question by way of habeas corpus. The court pointed out that it would be senseless to refuse such a defense in a criminal proceeding since immediately after conviction the same defense could be presented by habeas corpus. If, therefore, the defense should not be allowed, the Act would be so construed as to require the courts "to march up the hill when it is apparent from the beginning that they will have to march down again."

This argument would seem to apply with equal plausibility to the requirement that a person go through the motions of reporting for induction before being deemed to have exhausted his administrative remedies. But, whatever the force of the reasoning, the decision was logically inevitable after the Falbo and Billings opinions, and the law on this point is now clear beyond question.

In passing, the court took occasion to express its opinion on another point on which the Circuit Courts have split: the substantial evidence rule. Because the statute makes decisions of local boards "final," the court said that they may be attacked only when the boards go beyond their jurisdiction by failing to act in conformity with the regulations, and that this point is reached "only if there is no basis in fact for the conclusion." In other words, the substantial evidence rule which usually applies in revieving administrative decisions does not obtain, and review may be had only if there is no evidence to support the finding of the draft board. It was remarked by the court that this is the scope of judicial inquiry in deportation cases where Congress has made the orders of the immigration authorities "final." Thus the Supreme Court has sanctioned the middle way followed in the Trainin case ${ }^{73}$ in preference to either the liberal "substantial evidence" rule or the harsh rule of ensuring only a full and fair hearing.

71. United States v. Estep, 150 F. (2d) 768 (C.C.A. 3d, 1945), rev'd, 327 U. S. 114 (1946), and cases cited therein; United States v. Rinko, 147 F. (2d) I (C.C.A. 7th, 1915).

72. 327 U.S. 114 (1946).

73. United States ex rel. Trainin v. Cain, 144 F. (2d) 944 (C.C.A. 2d, 1944), discussed subra pp. 265-6. 